\title{
Model Penilaian Risiko Kebakaran Perkotaan dengan Sistem Pakar berbasis Gis Grid-Based
}

\section{Sabrillah Taridala ${ }^{1}$, Ananto Yudono ${ }^{1}$, M. Isran Ramli ${ }^{2}$, dan Arifuddin Akil ${ }^{1}$}

\author{
${ }^{1}$ Departemen Arsitektur, Fakultas Teknik, Universitas Hasanuddin, Makassar, Indonesia \\ ${ }^{2}$ Departemen Sipil, Fakultas Teknik, Universitas Hasanuddin, Makassar, Indonesia \\ ${ }^{1}$ Email : abhytaridala@yahoo.co.id
}

Diterima : Maret 2017 ; Direvisi : Juli 2017; Dipubikasikan: September 2017

(C) 2017 Fakultas Geografi UGM dan Ikatan Geograf Indonesia.

\begin{abstract}
Abstrak Kota Kendari merupakan suatu kawasan perkotaan dengan luas wilayah terkecil dan jumlah penduduk terpadat di Provinsi Sulawesi Tenggara. Bencana kebakaran di Kota Kendari sering terjadi dan telah menimbulkan kerugian yang cukup banyak, hingga menelan korban jiwa. Penelitian ini bertujuan untuk melakukan penilaian terhadap tingkat risiko bencana kebakaran di Kota Kendari dengan menggunakan pendekatan Sistem Pakar (Expert System) berbasis Sistem Informasi Geografis (SIG). Hasil penelitian menujukkan bahwa tingkat risiko kebakaran di Kota Kendari terklasifikasi dalam empat kelas, yaitu tingkat risiko kebakaran sangat tinggi sebanyak 206 grid, tingkat risiko kebakaran tinggi sebanyak 6.815 grid, tingkat risiko kebakaran rendah sebanyak 46.175 grid, dan tingkat risiko kebakaran sangat rendah sebanyak 54.640 grid. Tingkat risiko kebakaran sangat tinggi di Kota Kendari merupakan kawasan terbangun yang berpenduduk padat dengan dominasi jenis material bangunan kayu dan campuran, terletak pada daerah dengan morfologi berbukit, dan aksesibilitas hanya dilalui oleh jalan umum yang memiliki lebar jalur lalu lintas $<4$ meter. Wilayah dengan tingkat risiko sangat rendah merupakan kawasan non-terbangun yang didominasi oleh badan air (sungai dan rawa), hutan dan sebagian kawasan pertanian (kebun). Kawasan tersebut bermorfologi datar, berbukit dan bergunung.
\end{abstract}

Kata kunci : Model, SIG, Sistem Pakar, Risiko Kebakaran

Abstract Kendari city is an urban area with the smallest area and the densest population in Southeast Sulawesi Province. Fire disaster in the city of Kendari often occurs and has caused considerable losses, to claim casualties. This study aims to assess the risk degree of fire disaster in Kendari City using Expert System Approach based on Geographic Information System (GIS). The results showed that the degrees of fire risk in Kendari City were classified into four classes, ie very high fire risk degree, 206 grid, high fire risk degree, 6,815 grid, low fire risk degree, 46.175 grid, and very low fire risk, as many as 54.640 grids. The high fire risk degree in Kendari City is a densely populated area, with dominance of wooden and mixed building materials, located in areas with hilly morphology, and accessibility is only by public roads with a traffic width of $<4$ meters, while fires with a very low-risk level is a non-built area dominated by water bodies (rivers and swamps), moist forests and some agricultural areas (gardens). This area is flat, hilly and mountainous.

Keywords: Model, GIS, Expert System, Fire Risk

\section{PENDAHULUAN}

Kawasan perkotaan di Indonesia mengalami pertumbuhan dalam setiap tahunnya (Ritohardoyo dan Murtomo, 1992; Arminah, 2002; Rachmawati dkk., 2004; Cahyadi dkk., 2011; Wardani dkk., 2016). Hal ini terindikasi oleh semakin meluasnya wilayah perkotaan, munculnya pusat-pusat pertumbuhan baru dan semakin bertambahnya jumlah penduduk yang tinggal dan beraktivitas di kawasan perkotaan (Prakoso dan Muta'ali, 2005; Rachmawati, 2008; Cahyadi dkk., 2012). Saat ini sebanyak 53\% penduduk Indonesia telah menjadi masyarakat perkotaan dan menetap di daerah perkotaan (Kementerian Pekerjaan Umum dan Perumahan Rakyat, 2015). Realitas umum perkembangan kota di Indonesia saat ini adalah pertumbuhan fisik ruang perkotaan yang tidak ditunjang oleh daya dukung lingkungan, perangkat dan regulasi yang ketat, akibatnya adalah kota tumbuh dan berkembang secara tidak terkontrol dan terkendali (Inoguchi dkk., 2003; Muta’ali dan Nugroho, 2016).

Penataan ruang kota yang dilakukan secara baik, akan mewujudkan keharmonisan antara lingkungan alam dan lingkungan buatan serta mewujudkan perlindungan fungsi ruang dan pencegahan dampak negatif terhadap lingkungan akibat pemanfaatan ruang kota (Yunus, 2000). Penataan ruang kota tersebut juga akan meningkatkan kemampuan atau mengurangi kerentanan wilayah terhadap berbagai risiko negatif yang mungkin terjadi, baik yang timbul secara alami maupun non-alami. Kegiatan penataan ruang secara sistematis dimulai dari tahap perencanaan, pemanfaatan, hingga pada kegiatan pengendalian pemanfaatan ruang. Salah satu aspek penting yang sering terabaikan dalam penataan ruang kota dan wilayah adalah aspek kebencanaan. 
Indonesia merupakan negara dengan potensi bencana yang cukup tinggi (Marfai dan Cahyadi, 2012) karena geografis wilayahnya yang terletak pada daerah khatulistiwa dengan morfologi yang beragam, adanya aktivitas pergerakan lempeng tektonik aktif (Marfai dkk., 2013) di sekitar perairan Indonesia, rangkaian gunungapi aktif serta sesar geologi yang merupakan zona rawan bencana gempabumi dan longsor. Potensi bencana tersebut meliputi potensi bahaya utama, seperti gempabumi, longsor, letusan gunungapi, tsunami dan banjir, serta potensi bahaya ikutan, seperti kebakaran, wabah penyakit dan konflik sosial. Potensi tertinggi bahaya ikutan berada pada wilayah perkotaan, yang memiliki kepadatan penduduk tinggi, kompleksitas penggunaan lahan, pemusatan aktivitas penduduk perkotaan, material bangunan, dan adanya daerahdaerah permukiman kumuh perkotaan.

Bencana terjadi ketika bahaya atau ancaman (hazard) bertemu dengan suatu kondisi wilayah atau masyarakat yang rentan (vulnerability), yang memiliki kemampuan rendah atau tidak memiliki kemampuan (capacity) untuk menanggapi atau menghadapi bahaya tersebut. Gabungan antara kedua hal tersebut menyebabkan terganggunya kehidupan masyarakat, seperti kehancuran rumah, kerusakan harta benda, pengungsian bahkan timbulnya korban jiwa (ISDR, 2004). Besarnya tingkat risiko wilayah perkotaan di Indonesia terhadap bencana dapat terlihat dari kerentanan yang dimiliki wilayah tersebut yang meliputi kerentanan fisik wilayah, sosial kependudukan dan ekonomi yang umumnya tinggi. Kerentanan fisik menggambarkan perkiraan tingkat kerusakan terhadap prasarana dan sarana lingkungan jika ada faktor berbahaya tertentu, pada aspek sosial kependudukan dan ekonomi berkaitan terhadap kapasitas dan kondisi masyarakat dalam menghadapi bencana.

Kebakaran merupakan salah satu jenis bencana yang sering terjadi pada kawasan perkotaan dan nonperkotaan. Kejadian kebakaran di perkotaan utamanya terjadi pada wilayah berpenduduk padat atau pada wilayah yang memiliki aktivitas tinggi, seperti kawasan komersial. Kebakaran pada wilayah non-perkotaan seringkali terjadi pada wilayah hutan dan sabana, baik yang memiliki vegetasi yang rapat ataupun bervegetasi jarang. Chainey and Ratcliffe (2005) menuliskan bahwa wilayah perkotaan yang berpenduduk padat, berkontribusi terhadap peningkatan kerentanan kebakaran perkotaan.

Kota Kendari merupakan salah satu kawasan perkotaan di Provinsi Sulawesi Tenggara yang memiliki luas wilayah daratan paling kecil dibandingkan dengan kabupaten yang lain, yaitu $267,37 \mathrm{Km}^{2}$ atau 0,7 persen dari luas wilayah daratan Provinsi Sulawesi Tenggara (BPS Kota Kendari, Tahun 2016). Jumlah penduduk yang banyak dengan luas wilayah yang relatif kecil berpotensi menimbulkan permasalahan bagi lingkungan perkotaan, seperti kepadatan bangunan, penggunaan lahan yang tidak beraturan, sanitasi yang buruk, prasarana jalan yang tidak memadai, tumbuhnya bangunan-bangunan semi permanen atau darurat yang bersifat temporer, hingga pada peningkatan kriminalitas (Mutảali, 2016). Mantra (2005) menuliskan bahwa kerentanan terhadap bencana kebakaran di kawasan perkotaan meliputi kondisi lingkungan (lebar jalan masuk, ketersediaan lapangan atau parkir), struktur bangunan dan jarak antar bangunan. Kebakaran di Kota Kendari sering terjadi dan telah menjadi sebuah bencana yang telah menimbulkan kerugian material yang tidak sedikit. Kejadian kebakaran tersebut pada tahun 2015 mengalami peningkatan hingga 30\% dari tahun sebelumnya. Tercatat telah terjadi 149 peristiwa kebakaran pada tahun 2015 dan 113 kejadian kebakaran pada tahun 2014. Peristiwa kebakaran terbesar pada tahun 2015 telah mengakibatkan kerugian hingga ratusan milyar rupiah (Dinas Pemadam Kebakaran Kota Kendari, Tahun 2016).

Penelitianmengenairisikokebakaran perkotaanini merupakan suatu langkah penting dan mendesak yang harus dilakukan karena intensitas kejadian kebakaran beserta dampaknya yang terjadi di Kota Kendari hingga saat ini semakin tinggi dan telah menimbulkan banyak kerugian. Penelitian ini akan menghasilkan suatu model penilaian tingkat risiko bencana kebakaran pada kawasan perkotaan. Pemodelan yang dilakukan tersebut merupakan upaya pencegahan dan mitigasi untuk peningkatan kesiapsiagaan dalam manajemen bencana kebakaran di Kota Kendari. Hal ini penting untuk menghadapi kejadian bencana atau memperkecil risiko dan dampak bencana yang mungkin ditimbulkan, sehingga kejadian kebakaran dapat diantisipasi, tidak berakibat fatal dan berulang.

\section{METODE PENELITIAN}

Pembangunan model penilaian tingkat risiko kebakaran perkotaan ini diterapkan di Kota Kendari, Provinsi Sulawesi Tenggara, menggunakan metode pendekatan Sistem Pakar (Expert System) berbasis Sistem Informasi Geografis (SIG). Sistem Pakar ini merupakan sistem yang berbasis pengetahuan, yaitu sistem yang menggunakan pengetahuan atau kecerdasan manusia yang dimasukkan ke dalam komputer untuk menyelesaikan permasalahan yang umumnya membutuhkan keahlian dari seorang pakar atau ahli.

Risiko kebakaran perkotaan dianalisis dengan terlebih dahulu menentukan faktor-faktor atau parameter yang berpengaruh terhadap kebakaran pada kawasan perkotaan, antara lain material bangunan yang mudah terbakar atau tidak mudah terbakar, kepadatan bangunan, akses jalan, dan jarak terhadap sumber air yang potensial untuk pemadaman kebakaran. Setiap faktor yang mempengaruhi diberi bobot berdasarkan besaran pengaruhnya terhadap kebakaran. Selain faktor 
yang berpengaruh, diidentifikasi pula faktor-faktor yang merupakan pembatas dan faktor-faktor yang tidak mendukung. Faktor-faktor tersebut kemudian dibuat menjadi sebuah metode dalam bentuk matriks yang merepresentasikan pengetahuan yaitu aturan (rule) dalam bentuk pasangan kondisi-aksi atau jikamaka (if-then). Secara umum, aturan (rule) tersebut direpresentasikan dalam bentuk persamaan 1 (Durkin, 1994).

If E1 [And / Or] E2 [And / Or] ... En

Then $\mathrm{H}(\mathrm{CF}=\mathrm{CFi})$

di mana:

E1... En : Fakta-fakta (evidence) yang ada
$\mathrm{H}$

$\mathrm{CF}$

: Hipotesis atau konklusi yang dihasilkan

: Tingkat keyakinan (Certainty Factor) terjadinya hipotesis $\mathrm{H}$ akibat adanya faktafakta E1 hingga En

Prosedur Sistem Pakar ini bekerja dengan metode yang menyerupai pengetahuan dan proses berpikir seorang pakar dalam menyelesaikan masalah yang rumit. Sistem ini dirancang menggunakan perangkat keras yaitu komputer personal atau komputer jinjing (laptop) dan perangkat lunak, yaitu aplikasi SIG (ArcGIS, ArcView GIS, Quantum GIS), AutoCAD, FORTRAN dan Quick Basic serta aplikasi pendukung lainnya. Sistem ini dijalankan pada sistem operasi Microsoft Windows. Kim et al (1990) dalam Gambar 1 memberikan gambaran hubungan keterkaitan antara Sistem Pakar dengan SIG dalam suatu model pengambilan keputusan .

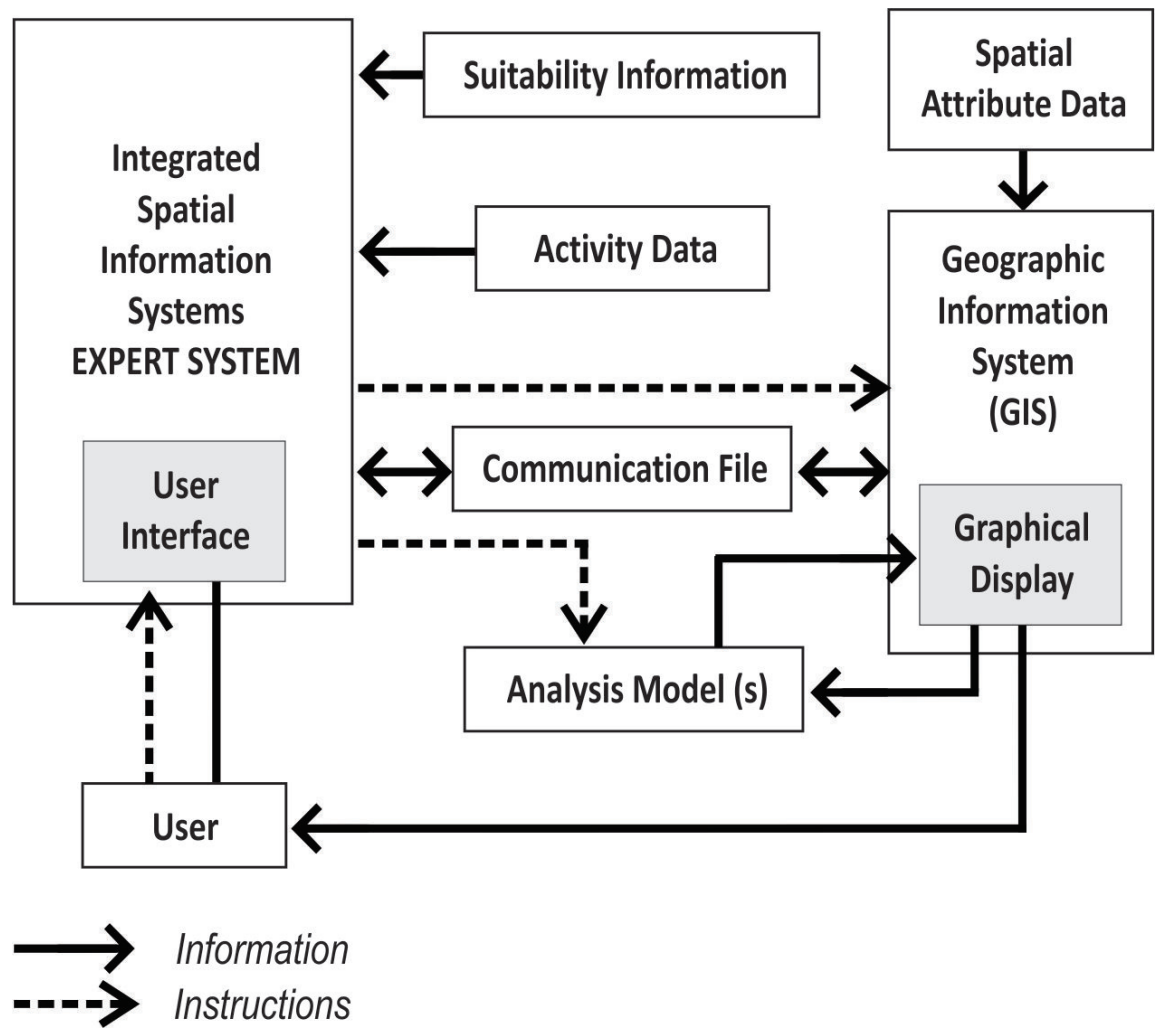

Gambar 1. Model pengambilan keputusan Sistem Pakar dan Sistem Informasi Geografis (Kim et al., 1990)

Sistem Pakar yang dirancang merupakan Sistem Pakar yang menggunakan pendekatan aturan (rulebased reasoning) yang berbasis pada Sistem Infomasi Geografis dengan menempatkan grid-grid geografis sebagai unit analisis (GIS grid-based). Grid yang digunakan berjumlah 107.836 grid, dengan ukuran grid masing-masing 50 meter x 50 meter atau seluas 0,25 hektar. Bahan yang digunakan dalam penelitian ini diperoleh dari beberapa sumber, yang meliputi data primer dan sekunder. Data primer diperoleh dari kegiatan survei lapangan, meliputi data penggunaan lahan, kawasan terbangun, jenis material bangunan dan lokasi sumber air yang potensial. Data sekunder diperoleh dari instansi terkait, termasuk citra satelit, peta batas administrasi, peta status kawasan hutan, dan peta fungsi jalan.

Sistem Pakar ini berfungsi untuk melakukan penilaian tingkat risiko kebakaran di wilayah 
perkotaan. Keluaran dari sistem tersebut merupakan hasil proses aturan yang ada pada basis pengetahuan. Aturan ini merupakan representasi dari pengetahuan yang dimiliki oleh pakar. Kerangka umum sistem ini digambarkan dalam bentuk diagram alir deskriptif formulasi pembuatan Sistem Pakar, seperti yang ditunjukkan pada Gambar 2.

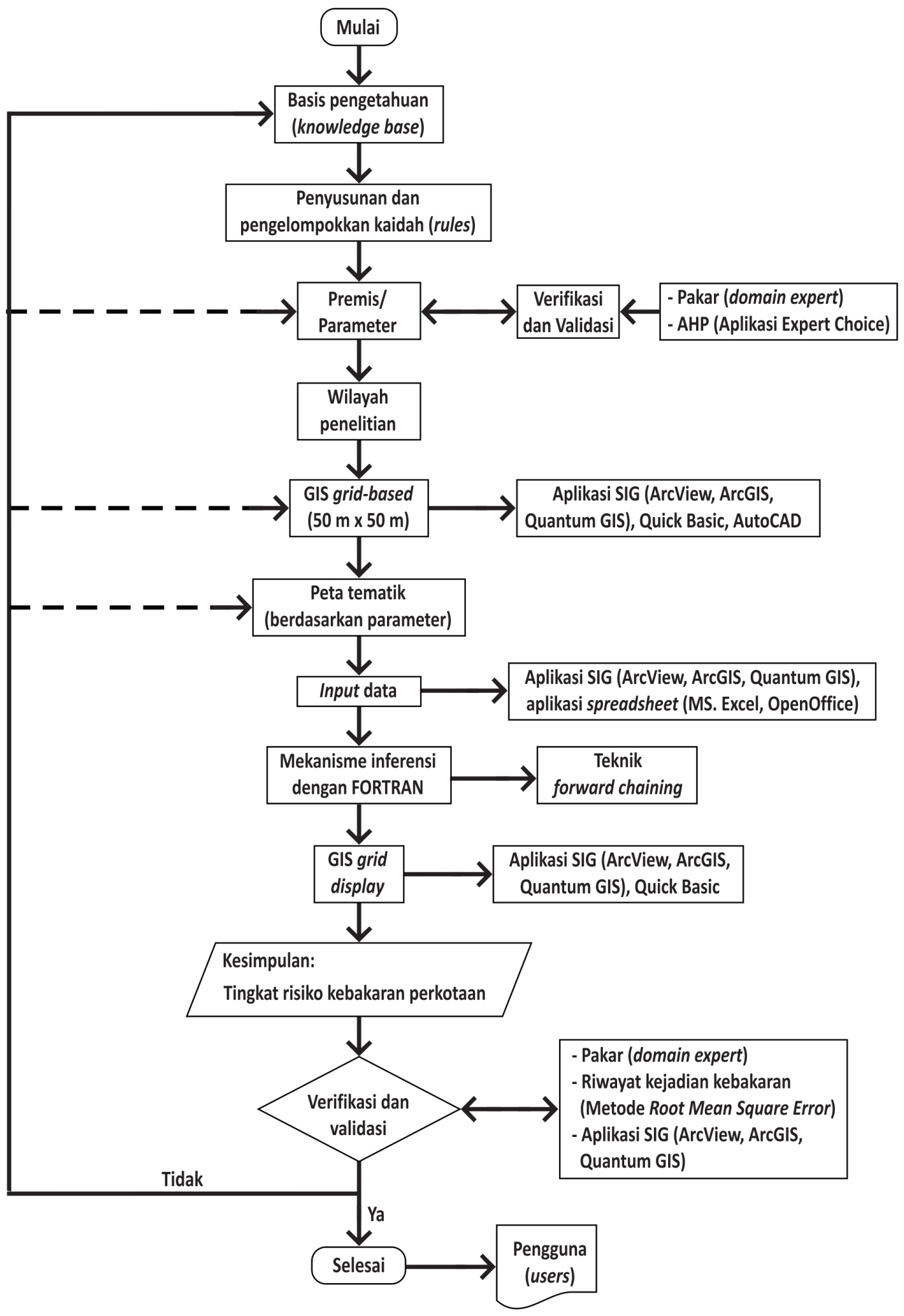

Gambar 2. Kerangka Umum Perancangan Sistem Pakar Berbasis SIG untuk Penilaian Tingkat Risiko Kebakaran Perkotaan 


\section{HASIL DAN PEMBAHASAN}

Sistem Pakar yang digunakan dalam penilaian tingkat risiko kebakaran di Kota Kendari terdiri dari 23 parameter atau rules, yang merupakan faktor penentu besaran tingkat risiko kebakaran di Kota Kendari. Secara garis besar, parameter-parameter tersebut meliputi dua kelompok yaitu (1) faktor penghambat/pembatas yaitu unsur-unsur sekat bakar (firebreaks), baik yang alami maupun sekat bakar buatan meliputi badan air, tanah terbuka tanpa vegetasi, saluran air, hutan lembab dan hutan mangrove. Parameter ini menjadi penghambat dalam penyebaran api atau kebakaran yang mutlak berpengaruh terhadap tingkat risiko kebakaran perkotaan, dan (2) faktor penentu yaitu parameterparameter yang mendukung terjadinya risiko kebakaran, meliputi tutupan lahan dengan vegetasi tertentu, kemiringan lereng, jenis material bangunan, kepadatan bangunan, jaringan jalan, jarak terhadap stasiun pemadam kebakaran dan jarak terhadap sumber air potensial untuk pemadaman kebakaran.

Rules atau aturan-aturan tersebut akan memberikan penilaian-penilaian risiko kebakaran berdasarkan pada kriteria-kriteria pendukung yang dibangun berdasarkan pengetahuan-pengetahuan yang telah diakuisisi. Setelah pemasukan nilai bobot parameter pada rules berdasarkan grid-based, maka sistem akan langsung melakukan perhitungan matematis. Seluruh nilai bobot parameter ini akan diproses oleh inference engine untuk menghasilkan kesimpulan berupa tingkat risiko kebakaran perkotaan. Matriks representasi penilaian tingkat risiko kebakaran perkotaan di kota kendari disajikan pada Gambar 3.

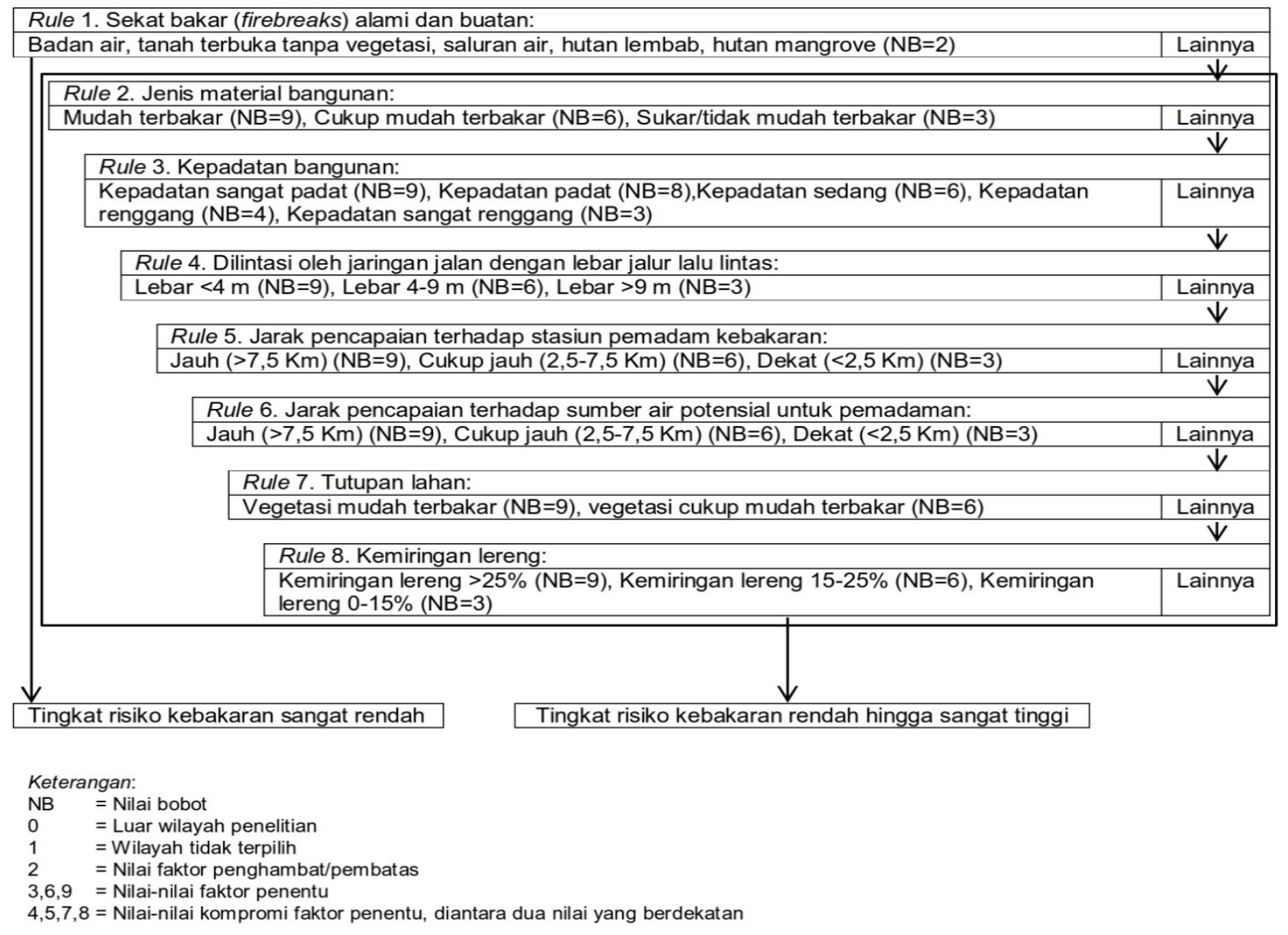

Gambar 3. Matriks Representasi Penilaian Tingkat Risiko Kebakaran Perkotaan di Kota Kendari

Proses pengambilan kesimpulan (inferencing) digambarkan dalam bentuk diagram alir yang menggambarkan alur logika dalam menghitung nilai implikasi (Gambar 4). Tahapan tersebut dilakukan melalui tahapan perhitungan dengan metode implikasi maksimum dan mengkomposisi semua keluaran hasil evaluasi rules yang selanjutnya menghasilkan sebuah nilai tunggal berupa tingkat risiko bencana kebakaran pada masing-masing grid, sebanyak jumlah grid yang ada. 


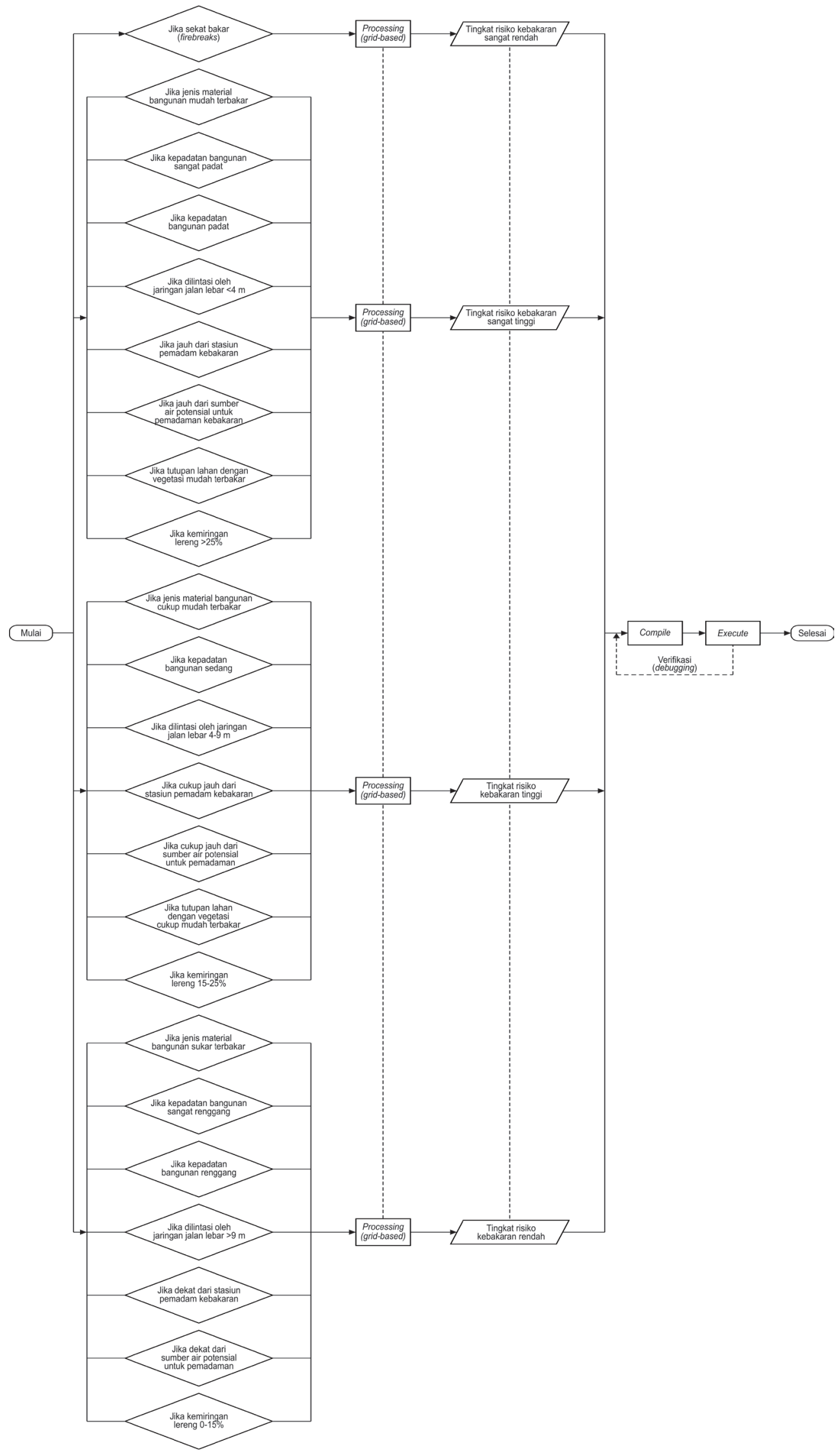

Gambar 4. Diagram Alir Proses Inferensi Penilaian Tingkat Risiko Kebakaran Perkotaan di Kota Kendari 
Tabel 1 menunjukkan luasan pada masingmasing kelas tingkat risiko kebakaran permukiman di Kota Kendari. Hasil analisis menunjukkan bahwa luas wilayah dengan tingkat risiko kebakaran sangat tinggi adalah yang paling kecil, sedangkan kelas risiko kebakaran sangat rendah memiliki luasan yang paling besar. Gambar 5 menunjukkan sebaran spasial dari tingkat risiko kebakaran di Kota Kendari hasil model yang dilakukan. Kelas risiko kebakaran sangat tinggi paling banyak terdapat di bagian timur kota, terutama di Utara Leluk Kendari.

Tabel 1. Output model Penilaian Tingkat Risiko Kebakaran di Kota Kendari dengan GIS Grid-Based

\begin{tabular}{cccc}
\hline No. & Grid terseleksi & Nilai & Kategori \\
\hline 1. & 206 & $>57$ & Tingkat Risiko Kebakaran Sangat Tinggi \\
2. & 6.815 & $>38 \leq 57$ & Tingkat Risiko Kebakaran Tinggi \\
3. & 46.175 & $>19 \leq 38$ & Tingkat Risiko Kebakaran Rendah \\
4. & 54.640 & $>0 \leq 19$ & Tingkat Risiko Kebakaran Sangat Rendah \\
Jumlah: & 107.836 & & \\
\hline
\end{tabular}

Sumber: Hasil Analisis (2017)

Tingkat Risiko Kebakaran:

Tingkat Risiko Kebakaran Sangat Tinggi Tingkat Risiko Kebakaran Tinggi Tingkat Risiko Kebakaran Rendah Tingkat Risiko Kebakaran Sangat Rendah

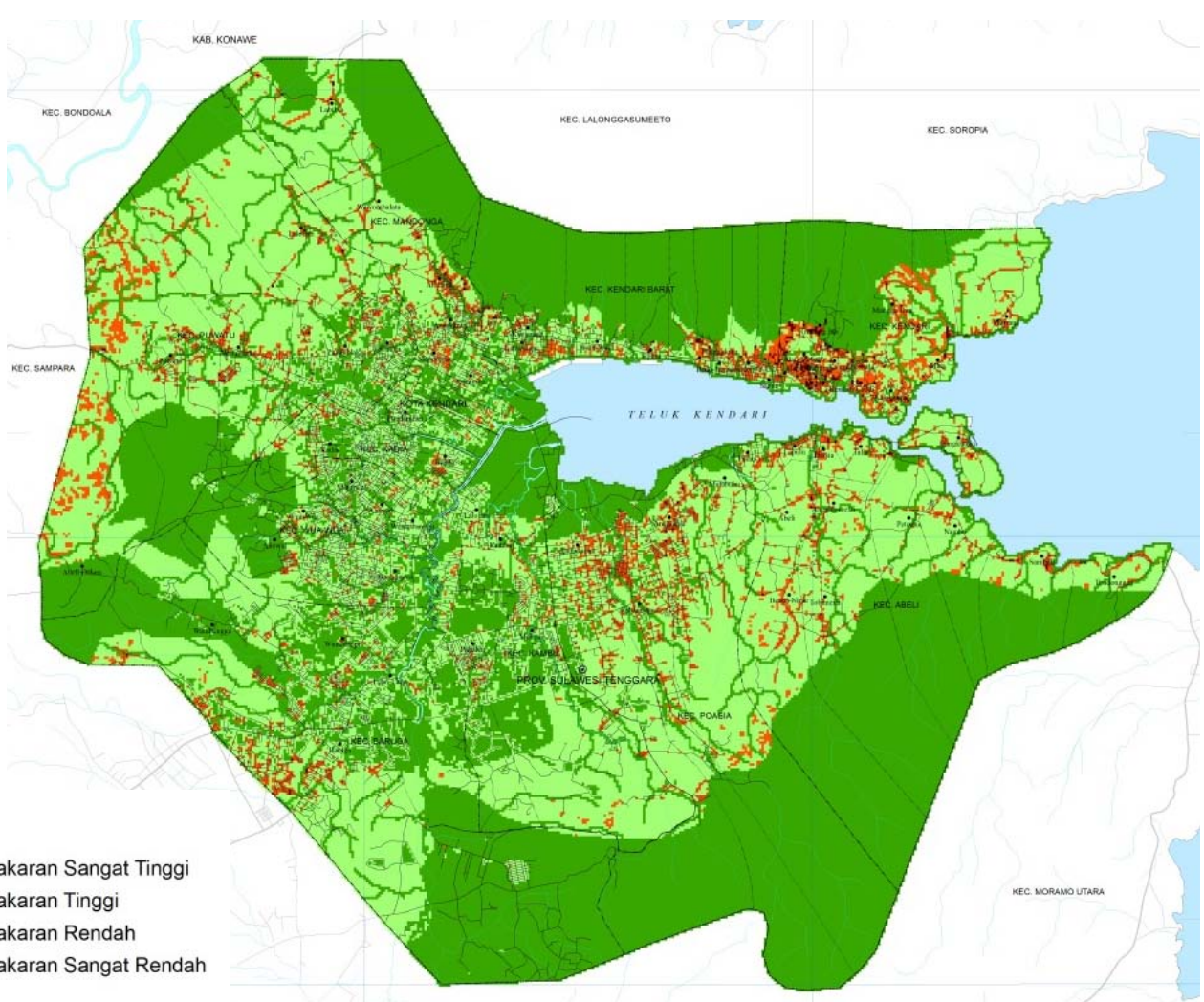

Gambar 5. Implementasi Sistem Pakar berbasis SIG dalam Penilaian Risiko Bencana Kebakaran di Kota Kendari
Proses verifikasi terhadap hasil penilaian tingkat risiko bencana kebakaran oleh sistem yang dibuat perlu dilakukan pasca pembuatan model. Gambar 6 menunjukkan bahwa coding program telah dibuat dengan benar dan bekerja sebagaimana mestinya. Tidak terdapatnya kesalahan pada proses compile, build dan execute ditunjukkan oleh nilai error yaitu 0 (nol), seperti yang ditampilkan pada Gambar 6. 


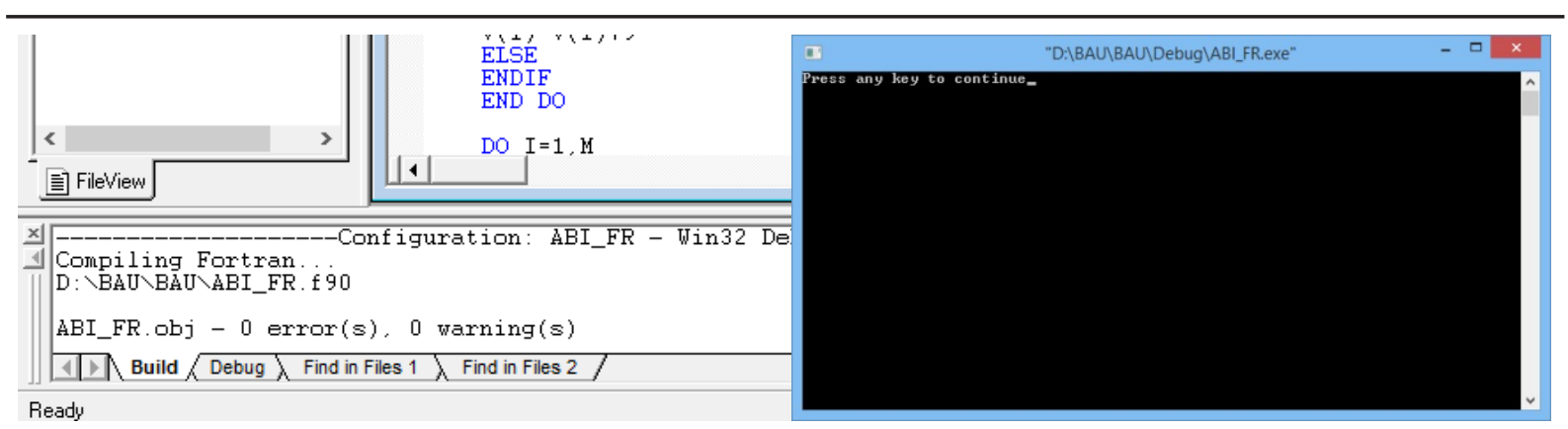

Gambar 6. Verifikasi Bug Terhadap Coding Penilaian Risiko Bencana Kebakaran Perkotaan dengan FORTRAN

Validasi output model penilaian risiko kebakaran di Kota Kendari dilakukan melalui wawancara dengan pakar dan melakukan pencocokkan antara hasil penilaian risiko dari model yang dibuat dengan riwayat kejadian kebakaran di Kota Kendari dari tahun 2012 2016. Hasil wawancara terhadap pakar menyatakan bahwa secara mayoritas penilaian risiko kebakaran dari output model sudah cukup sesuai dengan kejadiankejadian kebakaran yang pernah terjadi sebelumnya. Hasil analisis menunjukkan bahwa kejadian kebakaran umumnya terjadi pada bangunan-bangunan yang mudah terbakar, wilayah dengan akses kendaraan yang sulit dan jauhnya jangkauan pemadam kebakaran terhadap lokasi kejadian. Hasil pencocokkan juga menunjukkan adanya beberapa pembiasan output model, pada umumnya terjadi pada kejadian kebakaran, di mana material bangunannya tidak mudah terbakar serta berada pada jalan utama, seperti kejadian kebakaran Pasar Baru Wua-wua dan Pasar Higienis Kota Kendari. Selain itu, dibuat pula perbandingan hasil prediksi model dengan kondisi aktual kejadian kebakaran di Kota Kendari dengan menggunakan metode Root Mean Square Error (RMSE), seperti yang disajikan pada Tabel 2 dan Gambar 7.

Tabel 2. Kesesuaian Output Model Penilaian Tingkat Risiko Kebakaran Terhadap Kondisi Aktual Kejadian Kebakaran di Kota Kendari

\begin{tabular}{cccccc}
\hline No. & Tahun & $\begin{array}{c}\text { Kejadian } \\
\text { (Histori) }\end{array}$ & $\begin{array}{c}\text { Sampel kejadian } \\
\text { (Histori) }\end{array}$ & $\begin{array}{c}\text { Kesesuaian kejadian } \\
\text { (Model) }\end{array}$ & Keterangan \\
\hline 1 & 2012 & 41 kejadian & 21 & 19 & Sample error \\
2 & 2013 & 39 kejadian & 20 & 17 & tolerance: $5 \%(0,05)$ \\
3 & 2014 & 113 kejadian & 57 & 44 & 63 \\
4 & 2015 & 149 kejadian & 75 & 19 & \\
5 & 2016 & 50 kejadian & 25 & & \\
\hline
\end{tabular}

Sumber: Hasil Analisis (2017)

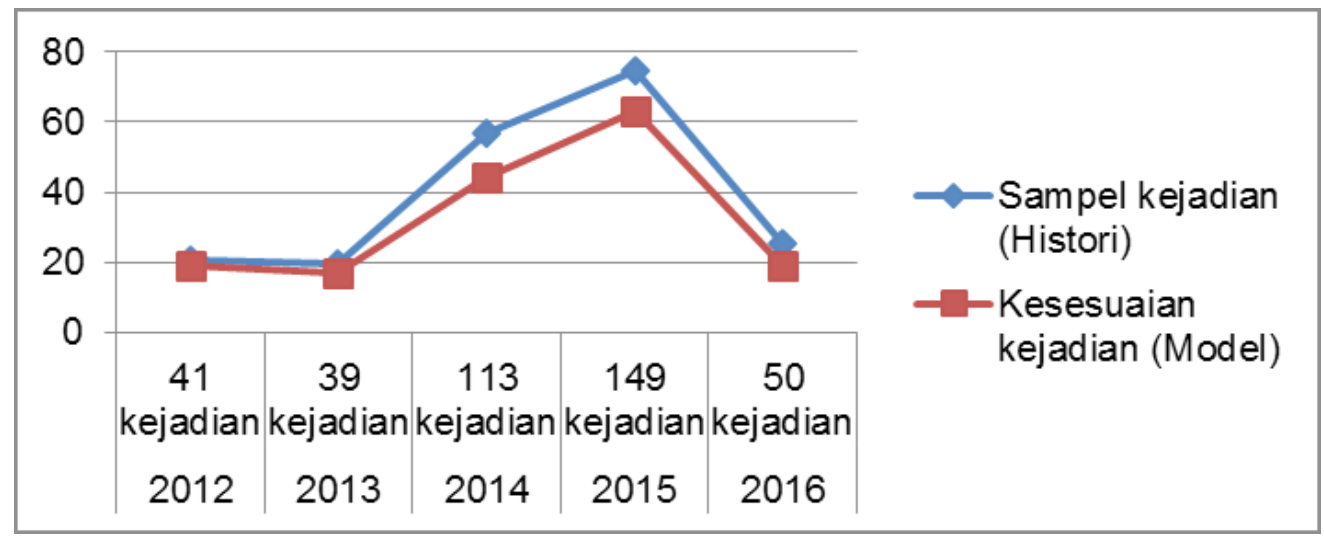

Gambar 7. Grafik perbandingan Output Model Penilaian Tingkat Risiko Kebakaran Terhadap Kondisi Aktual Kejadian Kebakaran di Kota Kendari 
Grafik pada Gambar 7 menunjukkan bahwa nilai prediksi tingkat risiko kebakaran perkotaan dari model yang dibangun mendekati nilai observasi atau kejadian yang sebenarnya, dengan nilai RMSE sebesar 8,51 . Validasi model penilaian risiko kebakaran juga dilakukan dengan membandingkan output model dengan faktor penghambat di lapangan, dan diperoleh hasil seperti pada Tabel 3 dan Gambar 8. Tabel 3 dan Gambar 8 menunjukkan kesesuaian luaran model terhadap faktor penghambat pada penilaian tingkat risiko kebakaran dalam penelitian ini.

Tabel 3. Kesesuaian output model terhadap faktor penghambat pada penilaian tingkat risiko kebakaran di Kota Kendari

\begin{tabular}{llcl}
\hline No. & \multicolumn{1}{c}{ Faktor penghambat } & Output sistem & Kesesuaian overlay \\
\hline $\begin{array}{l}\text { Sekat bakar (firebreaks) alami dan } \\
\text { buatan (badan air, tanah terbuka tanpa } \\
\text { vegetasi, saluran air, hutan lembab, } \\
\text { hutan mangrove) }\end{array}$ & 47.961 grid & $\begin{array}{l}\text { ・ } 41.474 \text { grid yang bertampalan } \\
\text { 1. }\end{array}$ & \\
\hline
\end{tabular}

Sumber: Hasil Analisis (2017)

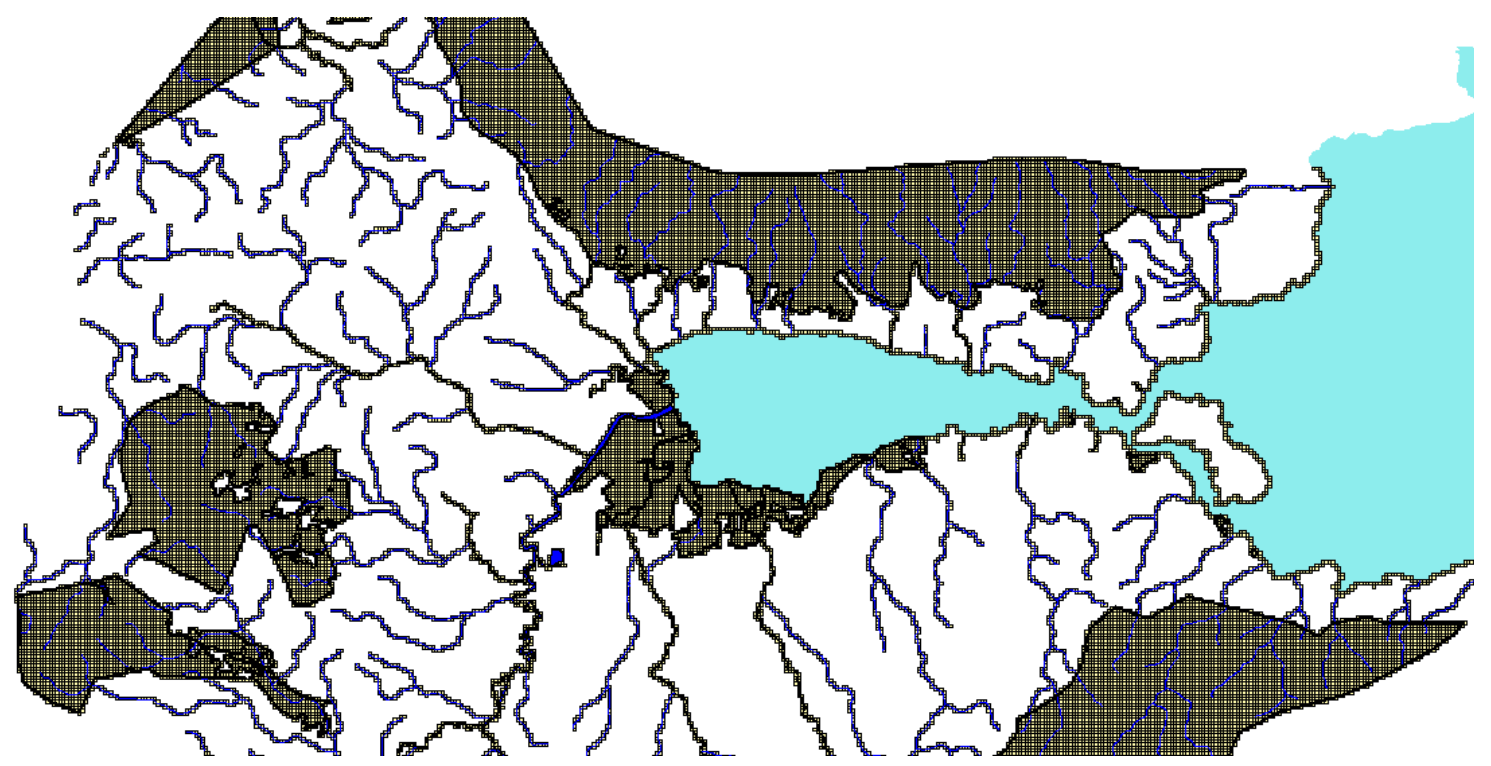

Gambar 8. Tumpang susun output model terhadap faktor penghambat pada penilaian tingkat risiko kebakaran di Kota Kendari

\section{KESIMPULAN}

Hasil kajian yang telah dilakukan menujukkan bahwa tingkat risiko kebakaran di Kota Kendari terklasifikasi dalam empat kelas, yaitu (1) tingkat risiko kebakaran sangat tinggi sebanyak 206 grid, (2) tingkat risiko kebakaran tinggi sebanyak 6.815 grid, (3) tingkat risiko kebakaran rendah sebanyak 46.175 grid, dan (4) tingkat risiko kebakaran sangat rendah sebanyak 54.640 grid. Tingkat risiko kebakaran sangat tinggi di Kota Kendari memiliki karakteristik berupa kawasan terbangun yang berpenduduk padat dengan dominasi jenis material bangunan kayu dan campuran, terletak pada daerah dengan morfologi berbukit, dan aksesibilitas hanya dilalui oleh jalan umum yang memiliki lebar $<4$ meter. Wilayah dengan tingkat risiko sangat rendah umumnya terdistribusi di kawasan non- terbangun yang didominasi oleh badan air (sungai dan rawa), hutan dan sebagian kawasan pertanian (kebun). Kawasan tersebut bermorfologi datar, berbukit dan bergunung.

\section{UCAPAN TERIMA KASIH}

Penulis mengucapkan terima kasih yang sebesarbesarnya pada semua pihak yang telah berkontribusi dalam kegiatan penelitian ini, khusus kepada Ketua Program Studi Pasca Sarjana Ilmu Arsitektur, Universitas Hasanuddin Makassar yang selalu memberikan arahan dan dorongan yang luar biasa dalam penyelesaian penelitian ini. Terima kasih pula kepada Isran Ramli dan Arifuddin Akil yang telah memperkaya khasanah keilmuan kepada penulis. 


\section{DAFTAR PUSTAKA}

Arminah, V.A. (2002). Kajian Pola Perkembangan Fisik Kota Surakarta Melalui Citra Spot nan Landsat TM. Majalah Geografi Indonesia, 16(2), 119 127.

Badan Pusat Statistik (BPS) Kota Kendari. 20d6. Kota Kendari dalam Angka (2016). Katalog BPS 1102001.7471. Kendari: Badan Pusat Statistik (BPS) Kota Kendari.

Cahyadi, A., Priadmodjo, A. \& Yananto, A. (2011). Criticizing The Conventional Paradigm of Urban Drainage. Proceeding The 3rd International Graduated Student Conference on Indonesia. Yogyakarta: Sekolah Pascasarjana Universitas Gadjah Mada.

Cahyadi, A., Wacano, D., Yananto, A., \& Wijaya, M.S. (2012). Keterbatasan dan Kendala-kendala dalam Prediksi Penggunaan Lahan Masa Depan Menggunakan Metode Cellular Automata (Studi Kasus Pemodelan Prediksi Penggunaan Lahan DAS Darang Tahun 2015). Prosiding Seminar Nasional Pengelolaan Sumberdaya Alam dan Lingkungan. Semarang: Universitas Diponegoro.

Chainey, S. \& Ratcliffe, J. (2005). GIS and crime mapping. West Sussex, England: John Wiley and Sons.

Dinas Pemadam Kebakaran Kota Kendari. (2016). Histori Kejadian Kebakaran Tahun 2012-2016 Kota Kendari. Kendari: Dinas Pemadam Kebakaran Kota Kendari.

Durkin, J. (1994). Expert Systems Design and Development. Englewood Cliffs, New Jersey: Prentice Hall International Inc.

Inoguchi, T., Newman, E. \& Paoletto, G. (2003). Kota dan Lingkungan: Pendekatan Baru Masyarakat Berwawasan Ekologi. Jakarta: LP3ES.

ISDR (International Strategy for Disaster Reduction). (2004). Learning from today's disasters for tomorrow's hazards. International Strategy for Disaster Reduction. The World Conference on Disaster Reduction. Kobe. Japan.

Kementerian Pekerjaan Umum dan Perumahan Rakyat. 2015. The Sixth Asia-Pacific Urban Forum Conference. Jakarta.

Kim, T.J., Wiggins, L.L., \& Wright, J.R. (1990). Expert Systems: Applications to Urban Planning. SpringerVerlag and Department of Urban and Regional Planning, University of Illinois, Champaign. USA.

Mantra, I.B.G.W. (2005). Kajian Penanggulangan Bahaya Kebakaran pada Perumahan. Suatu Kajian Pendahuluan di Perumahan Sarijadi Bandung. Jurnal Permukiman Natah, 3(1), 1 - 61.
Marfai, M.A. \& Cahyadi, A. (2012). Penentuan Tipologi Pesisir Rawan Tsunami di Provinsi D.I. Yogyakarta Berdasarkan Analisis Regional Dan Local Site Effect. Jurnal Spatial, 10(2), 1-6.

Marfai, M.A., Cahyadi, A. \& Anggraini, D.F. (2013). Tipologi, Dinamika dan Potensi Bencana di Pesisir Kawasan Karst Kabupaten Gunungkidul. Forum Geografi, 27(2), 147-158.

Mutaali, L. \& Nugroho, A.R. (2016). Perkembangan Program Penanganan Permukiman Kumuh di Indonesia dari Masa ke Masa. Yogykarta: Gadjah Mada University Press.

Prakoso, B.S. \& Muta'ali, L. (2005). Dinamika Sistem Kota-Kota dan Pemilihan Alternatif Pusat Pertumbuhan Baru di Propinsi Daerah Istimewa Yogyakarta. Majalah Geografi Indonesia, 19(2), $155-179$.

Rachmawati, R. (2008). Pengembangan Pusat Pelayanan Ekonomi di Pinggiran Kota Sebagai Alternatif Penanganan Problematik Ruang di Kota Yogyakarta. Majalah Geografi Indonesia, 22(1), 73 - 90.

Ritohardoyo, S. \& Murtomo, R. (1992). Perubahan Hirarki Kota Menengah di Pulau Jawa. Majalah Geografi Indonesia, 6(9), 27 - 43.

Wardani, D.W., Danoedoro, P. \& Susilo, B. (2016). Kajian Perubahan Penggunaan Lahan Berbasis Citra Satelit Penginderaan Jauh Resolusi Menengah dengan Metode Multi Layer Perceptrondan Markov Chain. Majalah Geografi Indonesia, 30(1), 9- 18 .

Yunus, H. S. (2000). Struktur Tata Ruang Kota. Pustaka Pelajar. Yogyakarta. 